\title{
KERJASAMA DAN KEKOMPAKAN SISWA DALAM PEMBELAJARAN FISIKA DI KELAS XII MIPA SMAN 3 KOTA JAMBI
}

\author{
Amalla Rizki Putri ${ }^{1}$, Maison ${ }^{2}$, dan Darmaji ${ }^{3}$ \\ 1,2,3 Program Studi Pendidikan Fisika FKIP Universitas Jambi, Jambi, Indonesia \\ Email: amallarizkiputri29@gmail.com
}

\section{Info Artikel}

Diterima:

\section{September 2018}

Disetujui:

05 November 2018

Dipublikasikan:

15 Desember 2018

\footnotetext{
Alamat Korespondensi:

amallarizkiputri29@gmail.com
}

\begin{abstract}
Abstrak:
Masalah yang terlihat pada saat observasi yaitu proses pembelajaran terlihat pembelajaran berorientasi pada hasil, hal ini membuat siswa menjadi saling berkompetisi padahal dalam pembelajaran fisika sangat dibutuhkan keterampilan kerjasama dan kekompakan dalam kelompok, menimbang mata pelajaran fisika dianggap sulit. Penelitian ini bertujuan untuk mengetahui kerjasama dan kekompakan siswa dalam pembelajaran fisika di kelas. Penelitian dilakukan terhadap 268 responden yang terdiri dari tujuh kelas dari XI MIPA di SMA Negeri 3 Kota Jambi. Metode yang digunakan dalam penelitian ini adalah deskriptif dengan pendekatan kuantitatif. Teknik pengumpulan data menggunakan kuesioner dengan dua faktor yaitu kerjasama (cooperation) dan kekompakan siswa (student cohesiveness). Analisis menggunakan statistik deskriptif. Hasil yang didapatkan bahwa tingkat kerjasama siswa dalam pembelajaran fisika di kelas termasuk dalam kategori "Sangat Baik" dengan nilai rata-rata 4,20 dalam skala 5,00 dengan nilai standar deviasi sebesar 0,84 . Tingkat kekompakan siswa dalam pembelajaran fisika di kelas termasuk dalam kategori "Baik" dengan nilai rata-rata 3,86 dalam skala 5,00 dengan nilai standar deviasi sebesar 0,88.
\end{abstract}

Kata kunci: kerjasama, kekompakan siswa 


\section{Pendahuluan}

Lingkungan belajar merupakan bagian dari proses belajar yang menciptakan tujuan belajar (dalam Winarno). Lingkungan belajar tidaklah lepas dari keberadaan siswa dalam belajar. Kebiasaan belajar siswa dipengaruhi oleh kebiasaan siswa dalam belajar di sekolah, di rumah maupun di masyarakat.

Kerjasama sangat dibutuhkan dalam bermasyarakat, mengingat manusia adalah makhluk sosial. Kerjasama dalam pembelajaran adalah suatu proses interaksi positif antarsiswa untuk mencapai tujuan yang sama. Kerjasama merupakan sikap positif yang terbukti dapat meningkatkan hasil belajar siswa.

Menurut Pamudji kerjasama pada hakikatnya mengindikasikan adanya dua pihak atau lebih yang berinteraksi secara dinamis untuk mencapai suatu tujuan bersama (dalam Nasia). Kerjasama dalam kelompok menurut Krisnadi diartikan sebagai kolaborasi yang berarti kegiatan belajar yang lebih menekankan kepada seberapa besar sumbangan masingmasing anggota kelompok terhadap pencapaian tujuan kelompoknya (dalam Suhardi, 2013). Kerjasama merupakan kebutuhan yang sangat penting bagi kelangsungan hidup (Hapsari, 2014). Kerjasama dalam pembelajaran dapat dilakukan oleh dua siswa atau lebih yang saling berinteraksi, menggabungkan tenaga, ide atau pendapat dalam waktu tertentu dalam mencapai tujuan pembelajaran sebagai kepentingan bersama (Yulianti, 2016). Hapsari menjelaskan hasil penelitiannya bahwa keterampilan kerjasama dalam pembelajaran sangat penting, siswa dapat bertukar gagasan dan informasi untuk mencari solusi kreatif serta keberhasilan dalam menyelesaikan tugas-tugas sangat bergantung pada sejauh mana mereka berinteraksi satu sama lain (dalam Anjani, 2017). Dijelaskan juga lebih lanjut oleh Nasia keterampilan kerjasama dalam kelompok adalah kepedulian satu orang atau satu pihak dengan orang atau pihak lain yang tercermin dalam satu kegiatan yang menguntungkan semua pihak dengan prinsip saling percaya, menghargai dan adanya norma yang mengatur (dalam Anjani 2017).

Berdasarkan pendapat para peneliti terdahulu, penulis menarik sebuah kesimpulan tentang definisi kerjasama yaitu merupakan kerja yang dilakukan oleh dua orang atau lebih untuk mewujudkan tujuan yang sama.

Kekompakan berkaitan dengan kerjasama. Jika siswa kompak berarti kerjasama yang mereka lakukan baik sehingga terbentuk kekompakan. Menurut Maksmum (2011) kohesivitas yang secara sederhana diartikan sebagai kekompakan, dapat didefinisikan sebagai proses dinamis yang tercermin dalam kecenderungan untuk menjalin dan mengembangkan kebersamaan yang padu guna mencapai suatu tujuan (dalam Syahrial). Munandar (2001) menyatakan semakin para anggota saling tertarik dan makin sepakat anggota terhadap sasaran dan tujuan kelompok maka makin kohesif kelompoknya (dalam Purwaningtyastuti).

Kelompok-kelompok yang sangat kohesif lazimnya terdiri dari individu-individu yang termotivasi untuk bersatu, sehingga akibatnya manajemen atau sebagian manajemen cenderung mengharapkan kelompok yang kohesif tersebut menunjukkan kinerja yang efektif (dalam Purwaningtyastuti, 2012). Menurut Maksmum kohesivitas yang secara sederhana diartikan sebagai kekompakan, dapat didefinisikan sebagai proses dinamis yang tercermin dalam kecenderungan untuk menjalin dan mengembangkan kebersamaan yang padu guna mencapai suatu tujuan (dalam Syahrial, 2013). Kohesivitas kelompok menurut Robbins adalah tingkat dimana anggota-anggota kelompok saling tertarik satu sama lain dan termotivasi untuk tinggal di dalam kelompok tersebut (dalam Permana, 2017). Kohesivitas adalah semua kekuatan yang menyebabkan anggota bertahan dalam kelompok, seperti kesukaan pada anggota lain dalam kelompok dan keinginan untuk menjaga atau meningkatkan status dengan menjadi anggota dari kelompok yang tepat (Permana, 2017).

Berdasarkan pendapat para peneliti terdahulu, penulis menarik sebuah kesimpulan tentang definis kekompakan yaitu merupakan sikap yang ditunjukkan setiap anggota kelompok dengan saling tertarik dan menyatu dalam kerjasama untuk mencapai tujuan kelompok.

Berdasarkan observasi di SMA Negeri 3 Kota Jambi, pada proses pembelajaran terlihat pembelajaran berorientasi pada hasil, hal ini membuat siswa menjadi saling berkompetisi. Seperti yang disampaikan oleh Rosita bahwa 
pembelajaran yang hanya berorientasi pada hasil belajar semata, tentu akan memberikan dampak kurang positif pada siswa karena siswa akan cenderung individualistis, kurang bertoleransi, dan jauh dari nilai-nilai kebersamaan. Selain itu, sekolah ini memiliki siswa yang berasal dari berbagai macam agama, suku, dan ras. Hal ini membuat sebagian siswa menjadi lebih bersifat individualis. Sifat individualis karena merasa tidak membutuhkan orang lain dan tidak suka bekerja dalam kelompok, siswa cenderung berkompetensi secara individual di kelas, bersikap tertutup terhadap teman, kurang memberikan perhatian terhadap teman sekelas, ingin menang sendiri dan sebagainya. Sementara pada era ini, guru lebih mengedepankan metode pembelajaran yang membutuhkan kerjasama antar siswa daripada metode ceramah yang hanya berpusat pada guru. Sehingga, pada proses pembelajaran fisika sangat dibutuhkan kerja-sama dan kekompakan yang baik.

Pembelajaran fisika yang berpacu pada konsep-konsep memerluan pemahaman yang tinggi. Terkadang, satu guru tidak dapat mengimbangi banyaknya siswa di kelas. Sementara, jika dalam satu pembelajaran terdapat dua guru, maka pembelajaraan akan kacau dan tidak terarah. Di beberapa tempat ditemukan siswa saling belajar bersama, berdiskusi, saling berbagi pengetahuan untuk mengimbangi hal tersebut. Kondisi inilah yang dianggap paling efisien dibandingkan harus menambah waktu belajar di bimbel. Sehingga siswa dituntut saling kerjasama agar pembelajaran lebih efektif dan efisien.

Pembelajaran fisika lainnya adalah dalam bentuk praktikum. Oleh karena alat, bahan dan waktu yang terbatas pembelajaran yang terdapat praktikum dibagi dalam beberapa kelompok. Agar praktikum berjalan lancar dan tujuan tercapai, maka siswa dituntut agar melakukan kerjasama yang baik antar kelompok, dan kompak dalam kelompok agar tercapainya pembelajaran dengan baik.

Berdasarkan hal yang telah dijelaskan, maka peneliti mengadakan penelitian mengenai "kerjasama dan kekompakan siswa dalam pembelajaran fisika di kelas XI MIPA SMA Negeri 3 Kota Jambi".

\section{Metode Penelitian}

\section{Desain Penelitian}

Pada penelitian ini terdapat dua variabel independen tanpa variabel dependen. Variabel independen pertama $\quad\left(\mathrm{X}_{1}\right)$ yaitu kerjasama siswa (cooperation), dan variabel independen kedua $\left(\mathrm{X}_{2}\right)$ yaitu kekompakan siswa (student cehesiveness). Karena tidak menggunakan variabel dependen, maka metode yang paling tepat adalah metode deskriptif. Dimana peneliti akan mendeskripsikan hasil penelitian secara rinci.

\section{Tempat dan Waktu Penelitian}

Penelitian bertempat di SMAN 3 Kota Jambi. Waktu penelitian dilakukan mulai dari Kamis tanggal 8 Maret sampai dengan Senin 12 Maret 2018 dengan perhitungan hari efektif selama 3 hari. Selama tiga hari, peneliti mengumpulkan data dari 7 kelas yaitu XI MIPA 1, 2, 3, 4, 5, 6, dan 7 .

\section{Target/Subjek Penelitian}

Populasi dalam penelitian ini adalah berjumlah 268 responden. Sampel yang digunakan adalah sebanyak populasi yaitu 268 responden.

Teknik sampling yang digunakan adalah Total Sampling. Total sampling (dalam Sugiyono) adalah teknik pengambilan sampel dimana jumlah sampel sama dengan populasi. Makin banyak sampel yang digunakan, makin kecil tingkat kesalahan. Mengingat teknik ini dianggap paling akurat dan terbebas dari pengaruh kesalahan sampel (sample errors), sehingga teknik sampling yang cocok digunakan dalam penelitian ini adalah Total Sampling.

\section{Prosedur}

Berdasarkan desain penelitian yang dipilih, prosedur penelitian yang digunakan diadaptasi dari Sugiyono (2016) adalah sebagai berikut. 


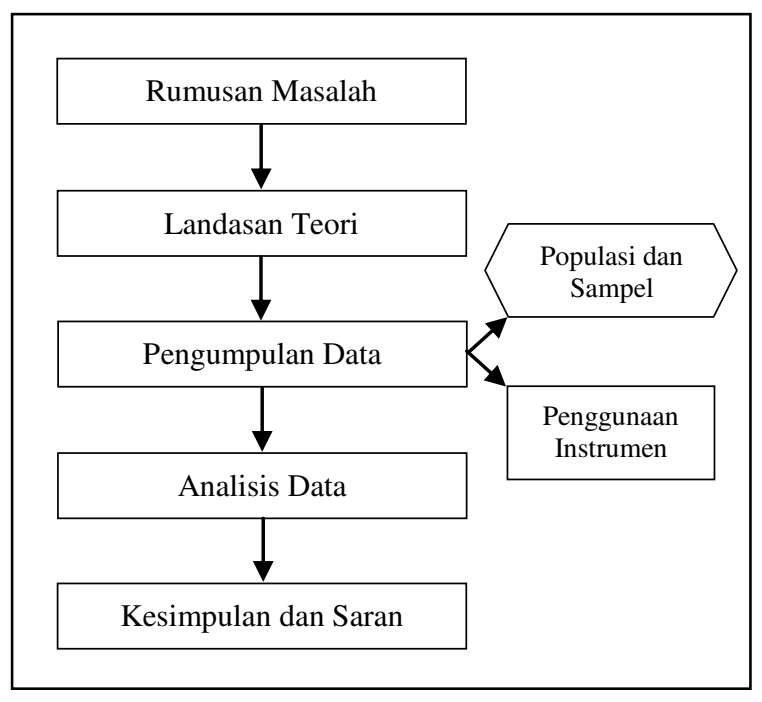

Gambar 1. Skema Makro Langkah-Langkah Penelitian
Teknik pengumpulan data menggunakan kuesioner. Untuk memudahkan dalam penelitian, penulis menggunakan kuesioner yang telah baku. Kuesioner yang digunakan adalah Kuesioner WIHIC (What Is Happening In This Class?) dikenal juga dengan persepsi siswa terhadap lingkungan belajar di kelas. Selanjutnya data akan dianalisis secara deskriptif dengan menggunakan statistik deskriptif melalui program MS. Exel.

\section{Hasil Penelitian dan Pembahasan}

Berikut ini hasil statistik deskriptif kerjasama siswa dalam pembelajaran fisika di kelas untuk tiap kelas disajikan pada tabel 1 dan penjabaran tiap item disajikan pada tabel 2 .

Tabel 1. Kerjasama Siswa dalam Pembelajaran Fisika di Kelas untuk Tiap Kelas

\begin{tabular}{cccccc}
\hline Kelas & $X$ & $\bar{X}$ & \% tiap kelas & $\sigma$ & $\sigma^{2}$ \\
\hline A & 1411 & 4,30 & $86,04 \%$ & 0,86 & 0,74 \\
B & 1268 & 4,17 & $83,42 \%$ & 0,80 & 0,64 \\
C & 1375 & 4,19 & $83,84 \%$ & 0,84 & 0,70 \\
D & 1345 & 4,10 & $82,01 \%$ & 0,95 & 0,91 \\
E & 1294 & 3,95 & $78,90 \%$ & 0,81 & 0,66 \\
F & 978 & 4,22 & $84,31 \%$ & 0,85 & 0,72 \\
G & 1330 & 4,49 & $89,86 \%$ & 0,66 & 0,44 \\
\hline Jumlah & $\mathbf{9 0 0 1}$ & $\mathbf{4 , 2 0}$ & & $\mathbf{0 , 8 4}$ & $\mathbf{0 , 7 1}$ \\
\hline
\end{tabular}

Berdasarkan tabel 1, dapat dilihat nilai rata-rata untuk seluruh kelas adalah sebesar 4,20 dengan nilai standar deviasi 0,84 ini menunjukkan data yang diperoleh representatif. Jika nilai rata-rata dibandingkan dengan tabel 3.4 tentang klasifikasi kategori seberapa baik kerjasama siswa dalam pembelajaran fisika di kelas, maka nilai 4,20 termasuk dalam rentang 4,01-5,00 yaitu "Sangat Baik". Kelas yang memiliki rata-rata tertinggi yaitu kelas $G$ dilanjutkan dengan kelas $\mathrm{A}, \mathrm{F}, \mathrm{C}, \mathrm{B}, \mathrm{D}$, dan $\mathrm{E}$. Berikut ini penyajian dalam bentuk diagram batang.

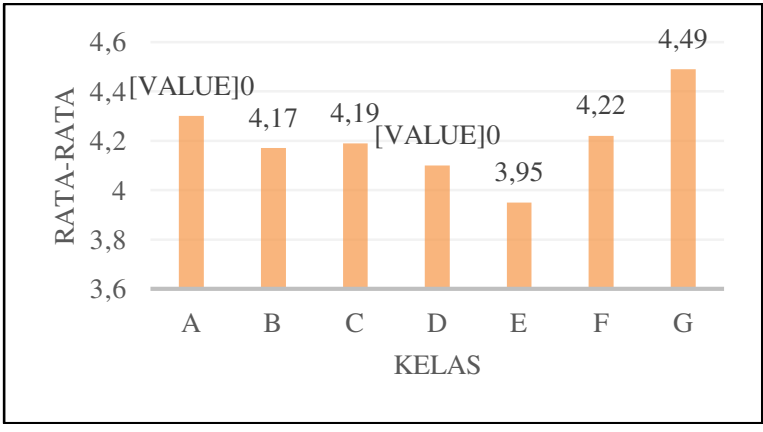

Gambar 2. Diagram Batang Kerjasama siswa dalam Pembelajaran Fisika di Kelas untuk Tiap Kelas 
Tabel 2. Kerjasama Siswa dalam Pembelajaran Fisika di Kelas

\begin{tabular}{ccccc}
\hline Pernyataan & $N$ & $X$ & $\bar{X}$ & $\%$ tiap item \\
\hline Item1 & 268 & 1202 & 4,48 & $13,35 \%$ \\
Item2 & 268 & 1258 & 4,69 & $13,98 \%$ \\
Item3 & 268 & 1165 & 4,35 & $12,94 \%$ \\
Item4 & 268 & 1204 & 4,49 & $13,38 \%$ \\
Item5 & 268 & 1076 & 4,01 & $11,95 \%$ \\
Item6 & 268 & 1034 & 3,86 & $11,49 \%$ \\
Item7 & 268 & 1005 & 3,75 & $11,16 \%$ \\
Item8 & 268 & 1057 & 3,94 & $11,74 \%$ \\
\hline Jumlah & $\mathbf{2 1 4 4}$ & $\mathbf{9 0 0 1}$ & $\mathbf{4 , 2 0}$ & $\mathbf{1 0 0} \%$ \\
\hline
\end{tabular}

Berdasarkan tabel 2, item yang menyumbang nilai tertinggi adalah item 2 dilanjutkan dengan item 4 , item 1 , item 3 , item 5 , item 8 , item 6 dan item 7 .

Item yang menyumbang nilai tertinggi adalah item 2 sebesar $13,98 \%$ yaitu pernyataan bahwa siswa berbagi buku-buku dan sumber belajar yang mereka miliki kepada siswa lainnya ketika menyelesaikan tugas. Sebagaimana dikatakan oleh Krisnadi (2007) bahwa kerjasama merupakan kolaborasi antar kelompok, dimana kegiatan belajar yang lebih menekankan kepada seberapa besar sumbangan masing-masing anggota kelompok terhadap pencapaian tujuan kelompok (dalam Suhardi). Item ini mem-buktikan bahwa untuk mencapai tujuan pembe-lajaran siswa bekerjasama saling meminjamkan sumber belajara (buku pelajaran) kepada anggota kelompok lainnya.

Item selanjutnya yang menyumbang nilai tertinggi kedua adalah item 4 sebesar $13,38 \%$ yaitu pernyataan bahwa siswa mengerjakan proyek bersama teman lainnya di kelas, dan item 1 sebesar $13,35 \%$ yaitu pernyataan bahwa siswa saling bekerjasama dengan siswa lainnya ketika menyelesaikan tugas. Hapsari (2014) menyatakan bahwa keberhasilan dalam menyelesaikan tugas-tugas sangat bergantung pada sejauh mana mereka berinteraksi satu sama lain. Idealnya, baik interaksi antarsiswa maka baik pula hasilnya. Untuk beberapa metode pembelajaran seperti diskusi dan praktikum membutuhkan kerjasama yang baik, dimana siswanya saling berinteraksi dengan baik (dalam Anjani). Hasil penelitian menggambarkan bahwa interaksi antar siswa termasuk dalam kategori baik, sehingga ini membuktikan kerjasama antarsiswa termasuk kategori baik karena interaksi yang baik.

Item 3 menyumbang nilai sebesar $12,94 \%$ dengan pernyataan bahwa terdapat kerjasama tim ketika belajar kelompok di kelas. Hal ini menggambarkan bahwa siswa melakukan kegiatan positif saat pembelajaran, mereka melakukan pekerjaan menguntungkan siswa lainnya sehingga timbul kerjasama yang baik dalam kelompok. Dikatakan oleh Yulianti (2016) kerjasama dalam pembelajaran dilakukan oleh dua orang siswa atau lebih yang saling berinteraksi, menggabungkan tenaga, ide atau pendapat dalam waktu tertentu dalam mencapai tujuan pembelajaran sebagai kepentingan bersama.

Item 5 menyumbang nilai sebesar $11,95 \%$ dengan pernyataan bahwa siswa belajar dari siswa lainnya di kelas. Karena terbatasnya waktu pembelajaran di kelas membuat siswa memiliki keterbatasan dalam belajar, terlebih lagi dalam satu kelas perbandingan guru dan siswa rata-rata adalah 1:40 sehingga memungkinkan siswa untuk belajar dari siswa lainnya yang lebih paham akan pelajaran untuk mencapai tujuan pembelajaran, inilah bentuk kerjasama siswa. Dijelaskan juga lebih lanjut oleh Nasia (2014) keterampilan kerjasama dalam kelompok adalah kepedulian satu orang atau satu pihak dengan orang atau pihak lain yang tercermin dalam satu kegiatan yang menguntungkan semua pihak dengan prinsip saling percaya, menghargai dan adanya norma yang mengatur (dalam Anjani).

Item 8 menyumbang nilai sebesar $11,74 \%$ dengan pernyataan bahwa para siswa bekerjasama bersama dalam mencapai tujuantujuan. Dalam pembelajaran, terdapat satu tujuan pembelajaran yang harus dicapai siswa. Oleh karena tujuan ini hanya satu untuk semua siswa, hendaknya siswa saling bekerjasama dalam mencapai tujuan pembelajaran. Pamudji (1985) mengatakan bahwa kerjasama pada hakikatnya mengindikasi adanya dua pihak atau lebih yang berinteraksi secara dinamis untuk 
mencapai suatu tujuan bersama. Ditambahkan pula oleh Hapsari (2014) yang mengatakan kerjasama adalah suatu bentuk interaksi sosial ketika tujuan anggota kelompok yang satu berkaitan erat dengan tujuan anggota yang lain atau tujuan kelompok secara keseluruhan sehingga setiap individu hanya dapat mencapai tujuan apabila individu lain juga mencapai tujuan.

Item 6 menyumbang nilai sebesar $11,49 \%$ dengan pernyataan siswa mengerjakan kegiatan kelas bersama siswa lainnya. Hal ini disampaikan oleh Zainudin (2013) kerjasama merupakan kepedulian satu orang atau satu pihak dengan orang atau pihak lain dengan prinsip saling percaya, menghargai dan adanya norma yang mengatur. Bekerjasama akan terjadi bila memiliki tujuan yang singkron atau sama. Dengan bekerjasama maka pencapaian tujuan pembelajaran akan lebih efektif dan efisien. Siswa memiliki tingkat kerjasama yang Tabel 3. Kekompakan Siswa dalam Pembelajaran tinggi apabila siswa bekerjasama dengan baik kepada semua siswa dan saling menguntungkan satu sama lainnya. Kerjasama pun tidak hanya pada pembelajaran bahkan juga untuk kegiatan lain. Hal tersebut sejalan dengan item 7 yang menyumbang nilai sebesar $11,16 \%$ dengan pernyataan siswa bekerjasama dengan siswa lainnya dalam kegiatan kelas.

Kerjasama siswa dikatakan sangat baik karena sebagian besar siswa merasa saling bekerjasama dengan siswa lain dalam kelompok untuk mengerjakan tugas dan proyek, menggunakan sumber belajar secara bersamasama, untuk memperdalam pemahaman siswa belajar dari siswa lainnya, bukan hanya bekerjasama dalam mencapai tujuan, tetapi juga dalam kegiatan kelas lainnya.

Berikut ini hasil statistik deskriptif kekompakan siswa dalam pembelajaran fisika di kelas untuk tiap kelas disajikan pada tabel 3 dan penjabaran tiap item disajikan pada tabel 4 .

\begin{tabular}{cccccc}
\hline Kelas & $X$ & $\bar{X}$ & \% tiap kelas & $\sigma$ & $\sigma^{2}$ \\
\hline A & 1271 & 3,88 & $77,50 \%$ & 0,85 & 0,72 \\
B & 1192 & 3,92 & $78,42 \%$ & 0,74 & 0,55 \\
C & 1309 & 3,99 & $79,82 \%$ & 0,79 & 0,62 \\
D & 1207 & 3,68 & $73,60 \%$ & 0,90 & 0,81 \\
E & 1225 & 3,73 & $74,70 \%$ & 0,86 & 0,74 \\
F & 862 & 3,72 & $74,31 \%$ & 1,21 & 1,47 \\
G & 1202 & 4,06 & $81,22 \%$ & 0,75 & 0,57 \\
\hline Jumlah & $\mathbf{8 2 6 8}$ & $\mathbf{3 , 8 6}$ & & $\mathbf{0 , 8 8}$ & $\mathbf{0 , 7 7}$ \\
\hline
\end{tabular}

Berdasarkan tabel 3, dapat dilihat nilai rata-rata untuk seluruh kelas adalah sebesar 3,86 dengan nilai standar deviasi 0,88 ini menunjukkan data yang diperoleh representatif. Jika nilai rata-rata dibandingkan dengan tabel 3.4 tentang klasifikasi kategori seberapa baik kekompakan siswa dalam pembelajaran fisika di kelas, maka nilai 3,86 termasuk dalam rentang 3,01-4,00 yaitu "Baik". Kelas yang memiliki rata-rata tertinggi yaitu kelas $G$ dilanjutkan dengan kelas C, B, A, E, F, dan D. Berikut ini penyajian dalam bentuk diagram batang.

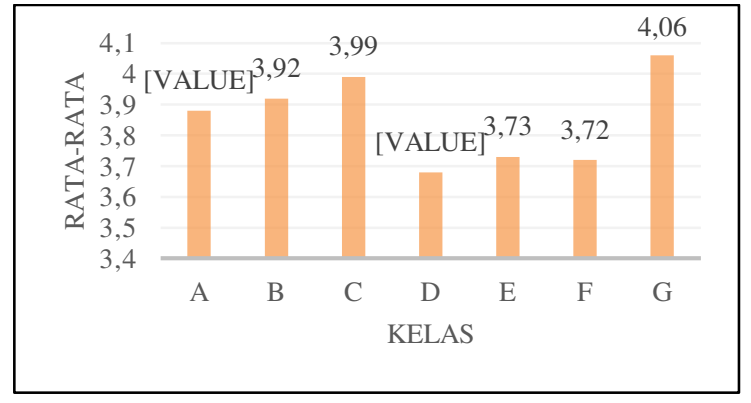

Gambar 3. Diagram Batang Kerjasama siswa dalam Pembelajaran Fisika di Kelas untuk Tiap Kelas 
Tabel 4. Kekompakan Siswa dalam Pembelajaran Fisika di Kelas

\begin{tabular}{ccccc}
\hline Pernyataan & $N$ & $X$ & $\bar{X}$ & $\%$ tiap item \\
\hline Item9 & 268 & 1039 & 3,88 & $12,57 \%$ \\
Item10 & 268 & 1077 & 4,02 & $13,03 \%$ \\
Item11 & 268 & 983 & 3,67 & $11,89 \%$ \\
Item12 & 268 & 1055 & 3,94 & $12,76 \%$ \\
Item13 & 268 & 1058 & 3,95 & $12,80 \%$ \\
Item14 & 268 & 1035 & 3,86 & $12,52 \%$ \\
Item15 & 268 & 1043 & 3,89 & $12,62 \%$ \\
Item16 & 268 & $\mathbf{8 2 6 8}$ & 3,65 & $11,83 \%$ \\
\hline Jumlah & $\mathbf{2 1 4 4}$ & & $\mathbf{3 , 8 6}$ & $\mathbf{1 0 0} \%$ \\
\hline
\end{tabular}

Berdasarkan tabel 4, item yang menyumbang nilai tertinggi adalah item 10 dilanjutkan dengan item 13 , item 12 , item 15 , item 9, item 14, item 11 dan item 16.

Item yang memberikan nilai tertinggi adalah item 10 yang menyumbang nilai sebesar $13,03 \%$ dengan penyataan bahwa siswa mengenal siswa lainnya di kelas. Kekompakan antarsiswa dapat dilihat dari apakah mereka mengetahui anggota kelas mereka, tidak akan bisa dikatakan kompak apabila siswa tidak mengetahui anggota kelasnya sehingga mereka dapat bekerja dengan baik sehingga timbul kekompakan antar siswa tersebut. Sebagaimana dikatakan Robbins (2012) kohesivitas kelompok adalah tingkat dimana anggota anggota kelompok saling tertarik satu sama lain dan termotivasi untuk tinggal di dalam kelompok tersebut (dalam Permana).

Item 13 menyumbang nilai sebesar $12,80 \%$ dengan pernyataan siswa bekerja dengan baik dengan semua orang di kelas. Dengan bekerjasama antar anggota di kelas, siswa dapat dikatakan kohesif. Kelompokkelompok yang sangat kohesif lazimnya terdiri dari individu-individu yang termotivasi untuk bersatu, sehingga akibatnya manajemen atau sebagian manajemen cenderung mengharapkan kelompok yang kohesif tersebut menunjukkan kinerja yang efektif (dalam Purwaningtyastuti).

Item 12 menyumbang nilai sebesar $12,76 \%$ dengan pernyataan siswa merasa semua orang di kelas adalah temannya. Suatu kelompok dapat dikatakan kompak apabila antar anggota kelompoknya memiliki hubungan yang baik. menurut Maksmum (2011) kohesivitas yang secara sederhana diartikan sebagai kekompakan, dapat didefinisikan sebagai proses dinamis yang tercermin dalam kecenderungan untuk menjalin dan mengembangkan kebersamaan yang padu guna mencapai suatu tujuan (dalam Syahrial). Hal ini sejalan dengan item 9 yang menyumbang nilai sebesar $12,57 \%$ dengan pernyataan siswa merasa bersahabat dengan mudah terhadap siswa lainnya, dan item 11 sebesar 11,89\% dengan pernyataan siswa merasa bersikap ramah dengan semua orang di kelas.

Item 15 menyumbang nilai sebesar $12,62 \%$ dengan pernyataan bahwa siswa merasa semua siswa di kelas menyukainya. Bila anggota kelompok saling menyukai satu sama lain dan dieratkan dengan ikatan persahabatan, kekom-pakan kelompok akan tinggi. Menurut Permana (2017) kohesivitas adalah semua kekuatan yang menyebabkan anggota bertahan dalam kelom-pok, seperti kesukaan pada anggota lain dalam kelompok dan keinginan untuk menjaga atau meningkatkan status dengan menjadi anggota dari kelompok yang tepat.

Item 14 menyumbang nilai sebesar $12,52 \%$ dengan pernyataan bahwa siswa membantu semua orang di kelas yang memiliki masalah dengan pekerjaan mereka. Munandar (2001) menyatakan semakin para anggota saling tertarik dan makin sepakat anggota terhadap sasaran dan tujuan kelompok maka makin kohesif kelompoknya (dalam Purwaningtyas-tuti). Sehingga siswa saling membantu ketika memiliki masalah. Hal ini sejalan dengan item 16 yang menyumbang nilai sebesar $11,83 \%$ dengan pernyataan siswa merasa mendapat bantuan dari siswa lainnya di kelas.

Kekompakan siswa dikatakan baik karena sebagian besar siswa merasa mengetahui dan berteman dengan semua siswa di kelas, saling menyukai antarsiswa, saling bekerjasama dan membantu dalam kesulitan dengan pekerjaan mereka. 


\section{Simpulan dan Saran}

Berdasarkan hasil penelitian dan pembahasan tentang kerjasama dan kekompakan siswa dalam pembelajaran fisika di kelas XI MIPA SMAN 3 Kota Jambi sebanyak 268 responden, maka dapat ditarik kesimpulan bahwa kerjasama siswa dalam pembelajaran fisika di kelas XI MIPA SMAN 3 Kota Jambi termasuk dalam kategori "Sangat Baik", dan kekompakan siswa dalam pembelajaran fisika di kelas XI MIPA SMAN 3 Kota Jambi termasuk dalam kategori "Baik". Saran yang dapat disampaikan untuk pihak siswa, guru dan sekolah, hendaknya lebih menekankan nilai-nilai cooperation dan student cohesiveness lebih baik lagi pada pembelajaran fisika khususnya agar efektifitas pencapaian tujuan pembelajaran lebih tinggi lagi. Dan untuk pihak mahasiswa, hendaknya lebih giat lagi dalam menuntut ilmu agar dapat menerapkan ilmunya kepada masyarakat secara sempurna.

\section{Daftar Pustaka}

Aisyah. Penggunaan Model Cooperative Learning Tipe Think Pair Share Untuk Meningkatkan Hasil Belajar PKn Pada Siswa Kelas IV SD Muhammadiyah 3 Palu. Kreatif Tadulako, 4(4): 297-305.

Alfayummi dan Tanti. Hubungan Persepsi Siswa Terhadap Lingkungan Belajar Dengan Motivasi Belajar Pada Mata Pelajaran Ilmu Pengetahuan Alam Terpadu Di Madrasah Tsanawiyah Negeri Olak Kemang. Prosiding, Seminar Nasional MIPA dan Pendidikan MIPA.

Anjani, D., Suciati dan Maridi, 2017. Profil Keterampilan Kerjasama Dalam Kelompok Siswa Kelas XI SMA Negeri 8 Surakarta Pada Materi Sistem Peredaran Darah. Seminar Nasional Pendidikan Sains II. 94-98.

Bagus D. Perbedaan Kohesivitas Siswa Yang Mengikuti Ekstrakurikuler Olahraga Dengan Siswa Yang Mengikuti Ekstrakurikuler Non Olahraga Di SMA Negeri 1 Sleman. Ilmu Keolahragaan.
Dwiyanto, A. dk, 2012, Hubungan antara kohesivitas kelompok dengan komitmen organisasi pada karyawan PT. NA. Pekalongan, Seminar Nasional Psikologi Islami, halaman 272.

Hapsari, N. S. dan Yonata, B., 2014. Keterampilan Kerjasama Saat Diskusi Kelompok Siswa Kelas XI IPA Pada Materi Asam Basa Melalui Penerapan Model Pembelajaran Kooperatif Di SMA Kemala Bhayangkari 1 Surabaya. Unesa of Chemical Education, 3(2): 181-188.

Limpo, J. N., Oetomo, H. dan Suprapto, M. H., 2013. Pengaruh Lingkungan Kelas Terhadap Sikap Siswa Untuk Pelajaran Matematika. Humanitas, 10(1): 37-48.

Nasia, S., Saneba, B. dan Hasdin. Meningkatkan Kerjasama Siswa Pada Pembelajaran PKn Melalui Value Clarification Technique (VCT) Di Kelas IV GKLB Sabang. Kreatif Tadulako, 2(3): 63-77.

Nurhayati, RP. Pengaruh Lingkungan Belajar Di Kelas Terhadap Hasil Belajar Siswa Pada Mata Pelajaran Kewirausahaan Di SMK Bina Mandiri Indonesia Surakarta Tahun Pelajaran 2014/2015. Universitas Sebelas Maret.

Permana, M. M. A. 2017. Persepsi Terhadap Kohesivitas Kelompok Kerja Dengan Intensi Turnover Pada Pramuniaga. Psikologi Teori dan Terapan, 8(1): 2432.

Purwaningtyastuti dkk. 2012. Kohesivitas Kelompok Ditinjau Dari Komitmen Terhadap Organisasi Dan Kelompok Pekerjaan. Kajian Ilmiah Psikologi, 1(2): 179-182.

Rosita I. Meningkatkan Kerjasama Siswa Melalui Pembelajaran Kooperatif Tipe Think Pair Share. Formatif, 3(1): 1-10.

Sugiyono. 2016. Metode Penelitian Pendidikan. Bandung: Alfabeta. 
Suhardi, 2013. Peningkatan Partisipasi Dan Kerjasama Siswa Menggunakan Model Kooperatif Tipe Jigsaw Pada Materi Protozoa Kelas X SMA Negeri Pengasih. Pendidikan Matematika Dan Sains, 1(2): 140-146.

Suparno, Paul. 2010. Metode Penelitian Pendidikan Fisika. Yogyakarta: Universitas Sanata Dharma.

Syahrial, M. I. A., 2013. Perbandingan Tingkat Kohesivitas Antara Siswa Rintisan Sekolah Berstandar Internasional (RSBI) dan Sekolah Standar Nasional (SSN). Pendidikan Olahraga dan Kesehatan, 1(2): 435-439.
Winarno, B., 2012. Pengaruh Lingkungan Belajar Dan Motivasi Berprestasi Terhadap Hasil Belajar Siswa Kompetensi KeahlianTeknik Otomasi Industri Sekolah Menengah Kejuruan Negeri 2 Depok Yogyakarta. Universitas Negeri Yogyakarta.

Yulianti, S. D., Djatmika, E. T. dan Santoso, A., 2016. Pendidikan Karakter Kerjasama Dalam Pembelajaran Siswa Sekolah Dasar Pada Kurikulum 2013. Teori dan Praksis Pembelajaran IPS, 1(1):

33-38. 